\title{
Nutritional condition determined using RNA/DNA ratios of the river pufferfish Takifugu obscurus under different salinities
}

\author{
Jin-Hyoung Kim ${ }^{1}$, Se-Joo Kim ${ }^{2}$, Gi-Sik Min ${ }^{2}$, Kyung-Nam Han ${ }^{1, *}$ \\ ${ }^{1}$ Department of Marine Sciences, and \\ ${ }^{2}$ Department of Biological Sciences, College of Natural Sciences, \\ Inha University, Incheon 402-751, South Korea
}

\begin{abstract}
We measured dry weight and nucleic acid (RNA/DNA) contents of larvae and juveniles of the anadromous river pufferfish Takifugu obscurus for 2 aquaculture salinity series in order to evaluate the effect of different rates of salinity change on fish growth and to determine appropriate rearing conditions for one of the most valuable aquaculture species. In addition, the effect of salinity during starvation was evaluated for 3 stages of development (larvae, juveniles and young fish). Analyses were performed at 1 to $2 \mathrm{~d}$ intervals over a period of 1 to $60 \mathrm{~d}$ after hatching (DAH). Differences in growth rates of the 2 groups were observed from 36 DAH until the end of the experiment. Specifically, the group in which salinity was increased by $1 \pm 0.5 \mathrm{psu} \mathrm{d}^{-1}$ grew faster than the group in which salinity was increased by $3 \pm 0.5 \mathrm{psu} \mathrm{d}^{-1}$. Significant differences in RNA/DNA ratios between both groups occurred from $30 \mathrm{DAH}$, with juvenile fish of the $1 \mathrm{psu} \mathrm{d}^{-1}$ group showing a higher ratio. Under starving conditions, the RNA content per individual decreased against a roughly constant DNA content. Significant differences in the RNA/DNA ratios were found between fed and starved larvae and juvenile fish. Consequently, we verified that RNA/DNA ratios could be used as an index of nutritional condition with respect to the effects of salinity change and recommend that maintaining stable salinity would be helpful in the aquaculture of anadromous river pufferfish.
\end{abstract}

KEY WORDS: Growth $\cdot$ Nutrition $\cdot$ Pufferfish $\cdot$ RNA/DNA ratio $\cdot$ Starvation $\cdot$ Salinity $\cdot$ Takifugu obscurus

\section{INTRODUCTION}

The early life stages of fish are the most susceptible to environmental fluctuation (Kucera et al. 2002). Therefore, the importance of eggs and larvae in fishery and aquaculture studies has been increasingly recognized since the 'critical period' concept was first published by Hjort (1914). He hypothesized that the period of transition from endogenous energy sources to exogenous feeding is critical, and that distribution and abundance of appropriately sized prey organisms during this period controls the subsequent success of the year-class. Various methods have been used to analyze and assess the condition of larval fish, such as the evaluation and correlation of weight and total length (TL) (Blaxter \& Hempel 1963, Yin \& Blaxter 1986) and histological methods (Gwak et al. 1999). Biochemical analysis using RNA/DNA ratios is recognized as a useful index of nutritional condition and growth of fish (Buckley 1980). Nucleic acids play a major role in growth and development, and DNA, which is stable under changing environmental conditions, has been used as an indicator of biomass and cell number (Dortch et al. 1983). RNA is directly involved in protein synthesis and larval growth is dependent on the amount of available RNA (Clemmesen 1987). Several investigations have shown that the whole-animal RNA/DNA ratio is correlated with both nutritional condition and growth rate in larval fish (Martin \& Wright 1987, Gwak et al. 2003, Catalan et 
al. 2006). Furthermore, the RNA/DNA ratio of larvae of several fish species is correlated with prey density (Buckley et al. 1984) and decreases rapidly during periods of starvation (Clemmesen 1987, Martin \& Wright 1987). The results of these investigations led to the widespread use of RNA/DNA ratios for the assessment of nutrional condition in various studies (Kono et al. 2003, Tardif et al. 2005).

Takifugu sp. (Tetradontiformes, Tetradontidae) have attracted the attention of scientists due to their unusual physiology, morphology and genomics (Aparicio et al. 2002). Although extensive research has been conducted on $T$. rubripes and $T$. nigroviridis, other puffer fish species have received little attention. The present study examined the nutritional condition of $T$. obscurus, which is commercially very important in the East China Sea, the South China Sea (Yang \& Chen 2003) and the Korean Peninsula, to determine optimal conditions for aquacultural production. Aquaculture production for this species in China has increased to $2600 \mathrm{t} \mathrm{yr}^{-1}$ since 2002 (Yang \& Chen 2006). T. obscurus is also a popular fish in Korea and fetches a premium price owing to its high-quality meat. Wild populations of this species are currently declining because of overexploitation and, possibly, environmental pollution (Yang \& Chen 2004). Thus, national programs to enhance stocks have recently been initiated in Korea and China. In Korea, fingerlings of T. obscurus have been released into river systems. T. obscurus lives in the bottom layer of inshore and inland waters and most of its growth takes place in the sea, but it spawns in brackish and freshwater. During the spawning season, sexually mature fish run into river estuaries and spawn in inland waters, including rivers, lakes and ponds (Kim et al. 2008). The fingerlings grow in inland water and either return to the sea the next spring or remain there for a few months before returning to the sea (Kato et al. 2005). Such a dynamic reproductive cycle exposes these fish to both freshwater and saltwater environments. Consequently, to successfully raise $T$. obscurus in a fish farming environment, 2 different water salinity conditions are needed. Frequently, pufferfish farms are located close to shore or near a river; therefore, freshwater and seawater become limiting factors regarding the specific location of a fish farm. Yang \& Chen (2006) reported that the considerable amount of freshwater consumed during the aquaculture process of this species hampers further development of its production, especially in areas where freshwater resources are limited, and they suggest investigating the possibility of raising this species in brackish water after establishing the salinity tolerance of its embryos. Consequently, locating pufferfish farms at nearby sites in seawater could be a temptation. However, the ability of larvae to withstand changes in salinity depends on their capacity to osmotically regulate their body fluids (Tandler et al. 1995). If this capacity exists, energy could be saved by reducing the metabolic cost of osmoregulation at more isotonic salinities, and this energy could instead be expressed in net growth.

We evaluated growth (in dry weight) and changes in nucleic acid composition (RNA/DNA ratio) in Takifugu obscurus in 2 culture salinity series and explored the effect of salinity change on nutritional condition of the fish. The results of the present study suggest appropriate rearing conditions for one of the most valuable aquaculture species.

\section{MATERIALS AND METHODS}

Broodstock management and incubation. Sexually mature Takifugu obscurus wild broodstock (male: $600 \pm 50 \mathrm{~g}$, female: $800 \pm 100 \mathrm{~g}$ ) were caught using gill nets from the mouth of the Im-jin River estuary $\left(126^{\circ} 39^{\prime} 00^{\prime \prime}\right.$ to $126^{\circ} 39^{\prime} 37^{\prime \prime} \mathrm{E}, 37^{\circ} 47^{\prime} 30^{\prime \prime}$ to $37^{\circ} 48^{\prime} 44^{\prime \prime}$ N, Gimpo, Kyunggi-do, Korea) during the spawning season (May). The broodstock was transported to the Aquatic Hatchery Center of Inha University (Tae-an, Chungchung-do, Korea), avoiding any physical stress. Fish were stocked in plastic tanks (radius $=0.6 \mathrm{~m}$, height $=1.0 \mathrm{~m}$ ) filled with an aerated, circulating freshwater volume of $0.8 \mathrm{~m}^{3}$ for $2 \mathrm{~d}$ to avoid further stress and until fertilization was induced by injections of human chorionic gonadotropin (HCG) of $1.0 \mathrm{ml} \mathrm{kg}^{-1}$ (Jang 1996). The artificially fertilized eggs were then incubated under natural photoperiods in plastic tanks (radius $=1.0 \mathrm{~m}$, height $=1.0 \mathrm{~m}$ ) with filtered freshwater $\left(10 \mu \mathrm{m}, 22 \pm 1^{\circ} \mathrm{C}, 1 \pm 0.5 \mathrm{psu}\right.$, dissolved oxygen 7.5 to $8.0 \mathrm{mg} \mathrm{l}^{-1}$ ) and a volume of $2.0 \mathrm{~m}^{3}$. River pufferfish larvae hatched $5 \mathrm{~d}$ after induced fertilization.

Rearing experiments. Larvae were randomly transferred into plastic tanks (radius $=1.0 \mathrm{~m}$, height $=$ $1.0 \mathrm{~m}$ ) with a water volume of $2.5 \mathrm{~m}^{3}$ immediately after hatching and stocked at a density of 10 ind. $\mathrm{l}^{-1}$. Rearing experiments, designed with 2 different salinity series, are shown in Fig. 1. The salinity of one group was increased by $1 \pm 0.5 \mathrm{psu} \mathrm{d}^{-1}$ until ambient salinity ( 30 to $32 \mathrm{psu}$ ) was achieved. This group was termed the ' $1 \mathrm{psu} \mathrm{d}^{-1}$ group'. The other group, in which the salinity was increased by $3 \pm 0.5 \mathrm{psu} \mathrm{d}^{-1}$ until ambient salinity was achieved, was termed the ' $3 \mathrm{psu} \mathrm{d}^{-1}$ group'. Each group was reared in 2 replicate tanks. Changes in salinity were achieved by diluting $10 \mu \mathrm{m}$-filtered seawater with fresh water at the start of the experiment. For each experimental group, $50 \%$ of the water was initially replaced with water of the final salinity as shown in Fig. 1. Follow- 


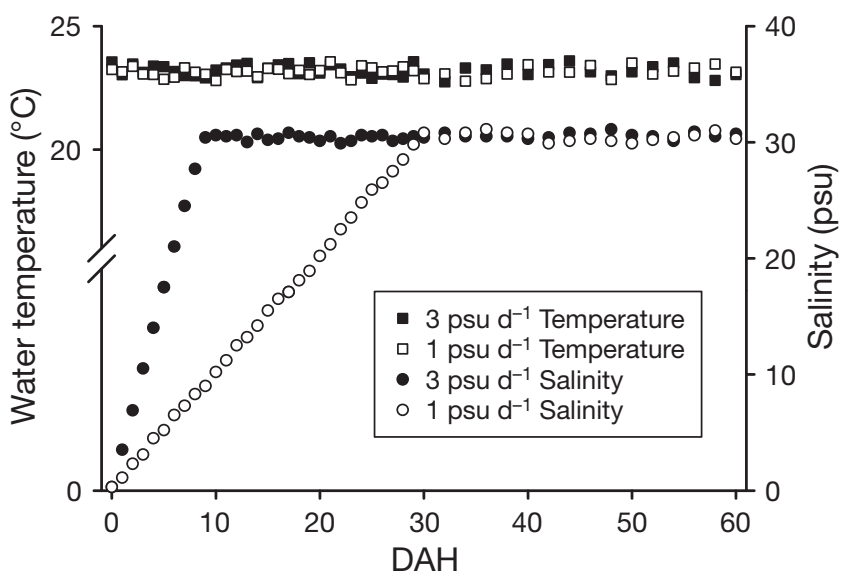

Fig. 1. Takifugu obscurus. Change of environmental conditions (water temperature and salinity) during the river pufferfish rearing experiments; DAH: days after hatching

ing this, the groups were supplied with a semicontinuous flow of water. Other environmental conditions, including water temperature $\left(23 \pm 0.5^{\circ} \mathrm{C}\right)$, dissolved oxygen concentration ( 7.5 to $8.0 \mathrm{mg} \mathrm{l}^{-1}$ ) and natural photoperiod were maintained at constant and equal levels.

The pufferfish were offered rotifers (Brachionus plicatilis, 5 ind. $\mathrm{ml}^{-1}$ ) cultured with Nannochloropsis sp. from 2 to $13 \mathrm{~d}$ after hatching (DAH). From 9 to $30 \mathrm{DAH}$, the pufferfish larvae were offered newly hatched Artemia nauplii (Great Salt Lake strain, 6 ind. $\mathrm{ml}^{-1}$ ), and an artificial pellet diet (200 to $300 \mu \mathrm{m})$ was given from $17 \mathrm{DAH}$ to the end of the experiment. The mortality rates in each aquarium were observed and recorded daily, and dead animals and uneaten food were removed daily.

Starvation experiments. To investigate the effect of starvation and salinity on fish growth, starvation experiments were performed in parallel to the rearing experiment for each developmental stage (larvae, juveniles and young fish). During the experiments, all environmental conditions except for salinity were maintained at constant and equal levels, and each group was divided into fed and unfed treatments. The salinity of each treatment was adjusted by the addition of diluted seawater until ambient salinity (30 to $32 \mathrm{psu}$ ) was reached. A detailed explanation regarding experimental conditions is shown in Table 1. Five hundred fish were randomly transferred from the rearing tank into each plastic tank with a water volume of $0.45 \mathrm{~m}^{3}$. Each treatment consisted of 2 replicate tanks. Dead fish were recorded and removed daily from each aquarium. The first starvation experiment ceased at $100 \%$ mortality; the second and third experiments stopped at $50 \%$ mortality.

Morphometric measurements and sampling. For morphometric measurements during the rearing experiment, 10 fish were randomly sampled from each tank. For biochemical analysis, 5 fish were carefully collected on a $150 \mu \mathrm{m}$ mesh net, rinsed with distilled water, pipetted into a $1.5 \mathrm{ml}$ Eppendorf tube or vinyl bag and immediately frozen $\left(-80^{\circ} \mathrm{C}\right)$. Sampling methods for biochemical analysis followed the method of Gwak et al. (2003). Sampling for the rearing experiment was performed early in the morning before food distribution to prevent contamination by gut contents. Samples were taken daily until 30 DAH and then at $2 \mathrm{~d}$ intervals for the remainder of the experiment. Sampling for the starvation experiment was performed daily; 5 fish were collected from each aquarium for morphometric measurement and biochemical analysis, respectively, by using the same procedure described above.

Both total lenght (TL) and standard lengths (SL) $( \pm 0.01 \mathrm{~mm})$ for larvae and early juveniles were measured under a microscope (SZ-11, Olympus). Vernier calipers were used for fish $>10 \mathrm{~mm}$ TL after anaesthetization in 100 ppm benzocaine (MS222). Dry weight ( $\pm 0.01 \mathrm{mg}$ ) was measured using a microbalance after drying at $60^{\circ} \mathrm{C}$ for $24 \mathrm{~h}$.

Growth rate (GR) and specific growth rate (SGR). GR and SGR are reported as follows:

$$
\begin{gathered}
\operatorname{GR}\left(\mathrm{mg} \mathrm{d}^{-1}\right)=\left[\ln \left(W_{2}\right)-\ln \left(W_{1}\right)\right]\left(T_{2}-T_{1}\right)^{-1} \\
\operatorname{SGR}(\%)=100 \times\left[\ln \left(W_{2}\right)-\ln \left(W_{1}\right)\right] T^{-1}
\end{gathered}
$$

Table 1. Takifugu obscurus. Environmental conditions during the starvation experiment. DAH: days after hatching; Larvae:

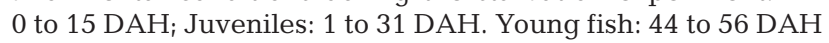

\begin{tabular}{|lccccc|}
\hline Experiment & DAH & $\begin{array}{c}\text { Experimental group } \\
\left(\mathrm{psu} \mathrm{d}^{-1}\right)\end{array}$ & $\begin{array}{c}\text { Salinity at start } \\
\text { of experiment (psu) }\end{array}$ & $\begin{array}{c}\text { Salinity change rates } \\
\left(\mathrm{psu} \mathrm{d}^{-1}\right)\end{array}$ & $\begin{array}{c}\text { Mortality } \\
(\%)\end{array}$ \\
\hline Expt 1 & 0 & 1 & 0 & 1 & 100 \\
Larvae & 0 & 3 & 0 & 3 & 1 \\
Expt 2 & 21 & 1 & 20 & 0 & 50 \\
Juveniles & 21 & 3 & 30 & 0 & 50 \\
Expt 3 & 44 & 1 & 30 & 0 & 50 \\
Young fish & 44 & 3 & & & 50 \\
\hline
\end{tabular}


where $W_{1}$ and $W_{2}$ are the initial and final dry weights, respectively, of fish on Days $T_{1}$ and $T_{2} ; \ln$ is the natural logarithm.

Biochemical analysis. Nucleic acid extraction: The method for extraction of nucleic acids was based on Sambrook et al. (1989). All chemicals used were biochemical grade. Total nucleic acids were extracted from the thawed samples by homogenizing with an extraction buffer $(250 \mathrm{mM}$ tris- $\mathrm{HCl}, 375 \mathrm{mM} \mathrm{NaCl}$, $25 \mathrm{mM}$ EDTA, $1 \%$ sodium dodecyl sulfate, $1 \% \beta$-mercaptoethanol). Then each sample was homogenized in $1 \mathrm{ml}$ saturated phenol ( $\mathrm{pH}$ 7.5) plus $100 \mu \mathrm{l}$ DEPC (diethylpyrocarbonate)-treated, distilled water for $30 \mathrm{~s}$ and then incubated for $5 \mathrm{~min}$ at room temperature. After the samples were centrifuged at $10000 \times g$ for $10 \mathrm{~min}$ at $4^{\circ} \mathrm{C}$, the supernatant was transferred into a new tube. The aqueous phases were mixed with $500 \mu \mathrm{l}$ of $100 \%$ isopropyl alcohol and $6 \mu \mathrm{l}$ of sodium acetic acid ( $\mathrm{pH} 5.2$ to 6.0 ). The mixtures were briefly shaken, incubated for $10 \mathrm{~min}$ at room temperature and then centrifuged at $10000 \times g$ for $10 \mathrm{~min}$ at $4^{\circ} \mathrm{C}$. After the supernatant was discarded, the nucleic acid precipitate (DNA plus RNA) was washed twice with $1 \mathrm{ml}$ of $75 \%$ ethanol and dissolved in DNase and RNase-free water.

Quantification of nucleic acids: Fluorometric assays for the quantification of nucleic acids were based on the method described by Clemmesen (1988) with some modifications following Schmidt \& Ernst (1995). Two aliquots (termed RNA and DNA aliquots) of the nucleic acid solution were processed in parallel. To the RNA aliquot $(5 \mu \mathrm{l}), 5 \mu \mathrm{l}$ DNase solution (DNase I, RNasefree, $10 \mu \mathrm{g} \mathrm{ll}^{-1}$; Roche) and $40 \mu \mathrm{l}$ DNase buffer (40 mM Tris-HCl, pH 7.9, $19 \mathrm{mM} \mathrm{NaCl}, 6 \mathrm{mM} \mathrm{MgCl}_{2}, 10 \mathrm{mM}$ $\mathrm{CaCl}_{2}$ ) were added. To the DNA aliquot $(5 \mu \mathrm{l}), 2 \mu \mathrm{l}$ RNase buffer (Roche), $5 \mu$ l RNase solution (RNase, DNase-free, $0.5 \mu \mathrm{g} \mathrm{ul}^{-1}$; Roche) and $33 \mu \mathrm{l}$ nuclease-free water were added. After incubation for $1 \mathrm{~h}$ at $37^{\circ} \mathrm{C}$, the reactions were terminated by adding $900 \mu \mathrm{l}$ of nuclease-free water and kept on ice. Following this, $50 \mu \mathrm{l}$ of the DNA and RNA aliquots were mixed with distilled water to a final volume of $900 \mu$ l. Following Mansfield et al. (1950), $50 \mu$ of SYBR Green II (CAMBREX BioSience) solution at a 1:100 dilution was then added and the solution incubated for 40 min under protection from light. The fluorescence was then measured in each sample using a spectrofluorometer (RF-5301, Shimadzu). The SYBR Green II fluorescence was determined at $490 \mathrm{~nm}$ excitation and $520 \mathrm{~nm}$ emission wavelength. Calibration curves for DNA and RNA with SYBR Green II, using $5 \mu \mathrm{g}$ herring sperm DNA (Sigma) and 1 to $5 \mu \mathrm{g}$ Escherichia coli ribosomal RNA (Sigma), were used as standardizations. A standard curve was run before each set of fluorescence determinations. The average DNA/RNA slope ratio was calculated fol- lowing the method described by Berdalet et al. (2005) and Caldarone et al. (2006) to facilitate the comparison of RNA/DNA values with other studies.

Statistical analysis. Sample means were compared using the unpaired independent sample $t$-test and 1-way ANOVA to detect differences between the 2 experimental groups over the course of the experiment. Differences were considered significant at $\mathrm{p}<0.05$, and all statistical analyses were performed using SPSS 10.0 software.

\section{RESULTS}

\section{Rearing experiment}

The mean dry weight of larvae right after hatching in the two treatments was $2.03 \pm 0.27 \mathrm{mg}$ for the $1 \mathrm{psu} \mathrm{d}^{-1}$ group and $2.73 \pm 0.22 \mathrm{mg}$ for the $3 \mathrm{psu} \mathrm{d}^{-1}$ group. Both groups increased steadily in weight until $29 \mathrm{DAH}$, except for a small reduction of initial dry weight by 5 DAH (Fig. 2).

A dry weight difference between the 2 groups in the rearing experiments became noticeable at around 32 DAH. After that, significant differences $(\mathrm{p}<0.05)$ were maintained from $36 \mathrm{DAH}$ until the end of the rearing experiment. Growth rates of the 2 groups during the experiment were $0.154 \mathrm{mg} \mathrm{d}^{-1}$ for the $1 \mathrm{psu} \mathrm{d}^{-1}$ group and $0.150 \mathrm{mg} \mathrm{d}^{-1}$ for the $3 \mathrm{psu} \mathrm{d}^{-1}$ group. DNA contents of both groups increased gradually during the rearing experiment with small fluctuations, though some reduction was observed on 46 and $50 \mathrm{DAH}$ (Fig. 3a). The RNA contents of both groups increased gradually to $3 \mathrm{DAH}$ but decreased at $6 \mathrm{DAH}$ and dramatically increased again from 7 to 14 DAH (Fig. 3a). There was no difference between RNA and DNA contents from 4 to 6 DAH. Both groups displayed a few peaks between 30 and 50 DAH with small fluctuations, and then greatly increased from 50 DAH onward. A significant difference in RNA contents appeared at 32 DAH ( $p<0.05)$, with the 1 psu d $^{-1}$ group being relatively higher than the $3 \mathrm{psu} \mathrm{d}^{-1}$ group until the end of the rearing experiment.

The RNA/DNA ratios of the larvae right after hatching dramatically decreased from $3 \mathrm{DAH}$ to 1.04 for the $1 \mathrm{psu} \mathrm{d}^{-1}$ group and 1.08 for the $3 \mathrm{psu} \mathrm{d}^{-1}$ group on $6 \mathrm{DAH}$ (Fig. 4). After an initial reduction in the RNA/DNA ratio, an increase starting at $7 \mathrm{DAH}$ was observed. The RNA/DNA ratios were similar for pufferfish larvae under both salinity change rates until 29 DAH ( $\mathrm{p}<0.05)$, but the RNA/DNA ratios were significantly different between juveniles of both salinity treatments, with that of the 1 psu $\mathrm{d}^{-1}$ group being higher than that of the $3 \mathrm{psu} \mathrm{d}^{-1}$ group, starting at $30 \mathrm{DAH}$ to the end of the experiment. When comparing 

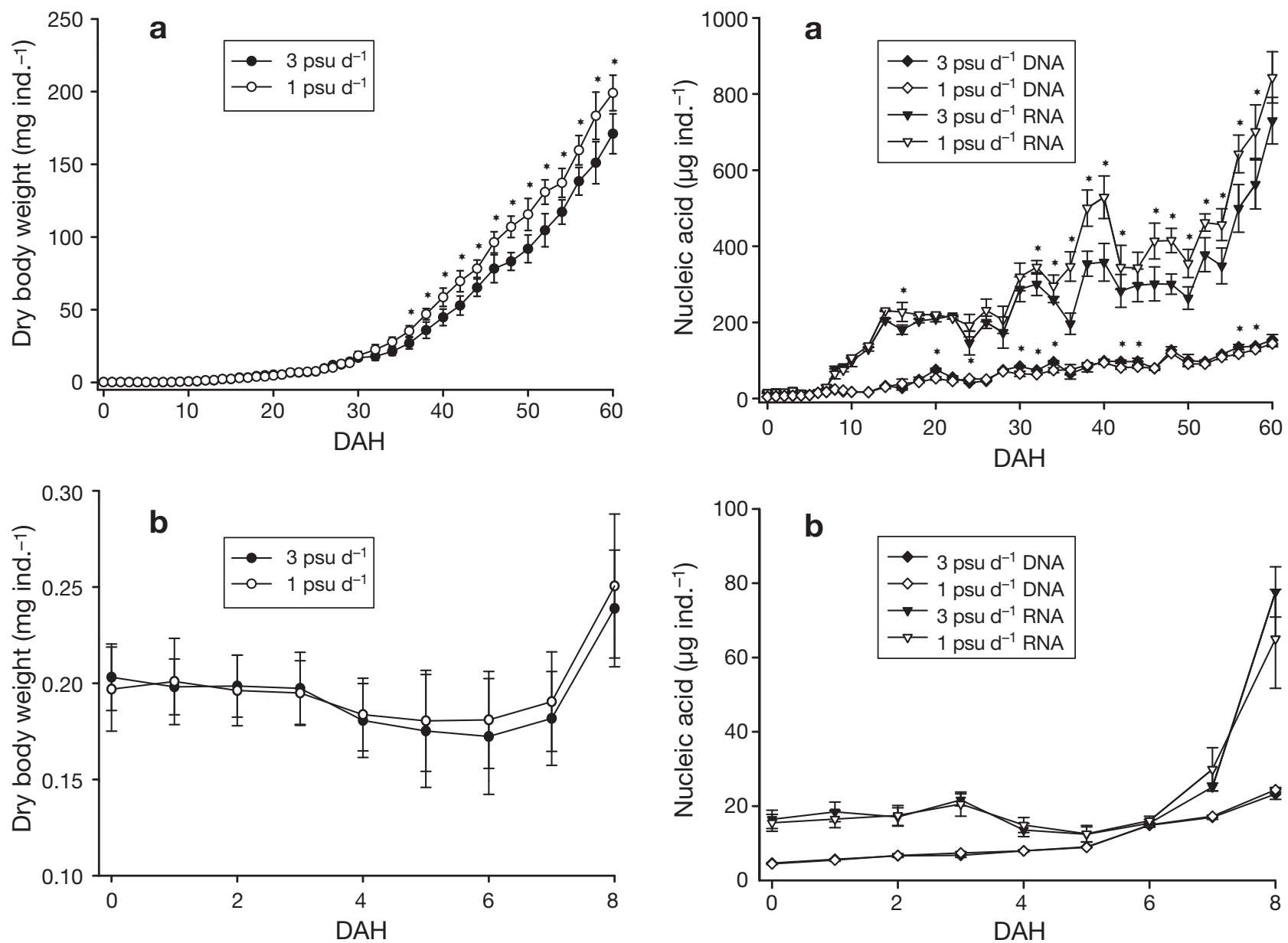

Fig. 2. Takifugu obscurus. Change of dry body weight (a) during the entire rearing experiment, (b) Days 1 to 8 in detail.

DAH: days after hatching, means $\pm \mathrm{SD}, \mathrm{n}=20{ }^{*}{ }^{*} \mathrm{p}<0.05$

the relationship between the RNA/DNA ratio and SPG, the $1 \mathrm{psu} \mathrm{d}^{-1}$ group showed a high correlation of $85 \%$ compared to the $3 \mathrm{psu} \mathrm{d}^{-1}$ group, which showed a correlation of $81 \%$ (Fig. 5).

\section{Starvation experiment}

Dry weight increased after hatching in the fed group at $8 \mathrm{DAH}$, while there was no increase of dry weight in the starved group (Fig. 6a). These significant differences in weight appeared $1 \mathrm{~d}$ earlier in the $3 \mathrm{psu} \mathrm{d}^{-1}$ group, and differences persisted until $100 \%$ mortality (15 DAH). Significant differences in the rate of weight loss were not observed between the salinity treatments.

In the second starvation experiment, significant differences $(p<0.05)$ in weight between the fed and starved groups appeared on Day 4 after initiation in

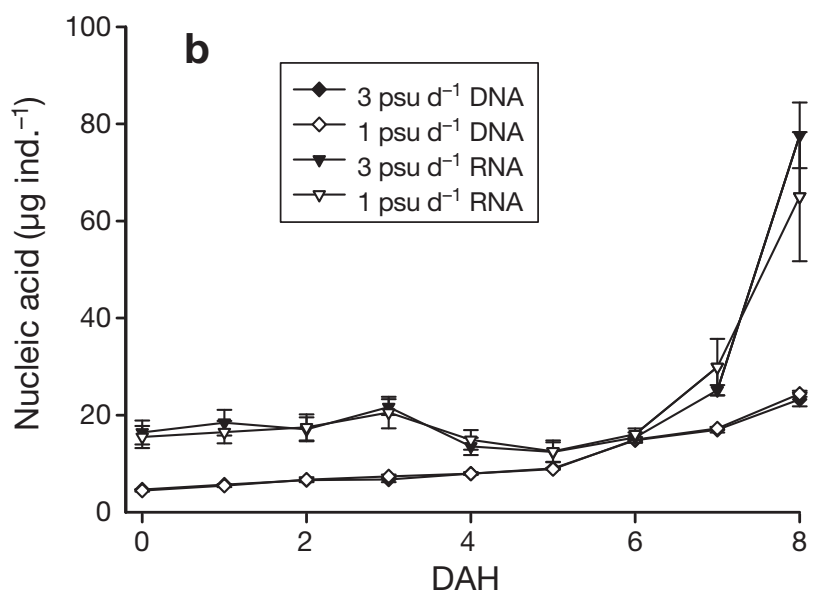

Fig. 3. Takifugu obscurus. Change of RNA and DNA content (a) during the entire rearing experiment, (b) Days 1 to 8 in detail. DAH: days after hatching; means $\pm \mathrm{SD}, \mathrm{n}=10,{ }^{*} \mathrm{p}<0.05$

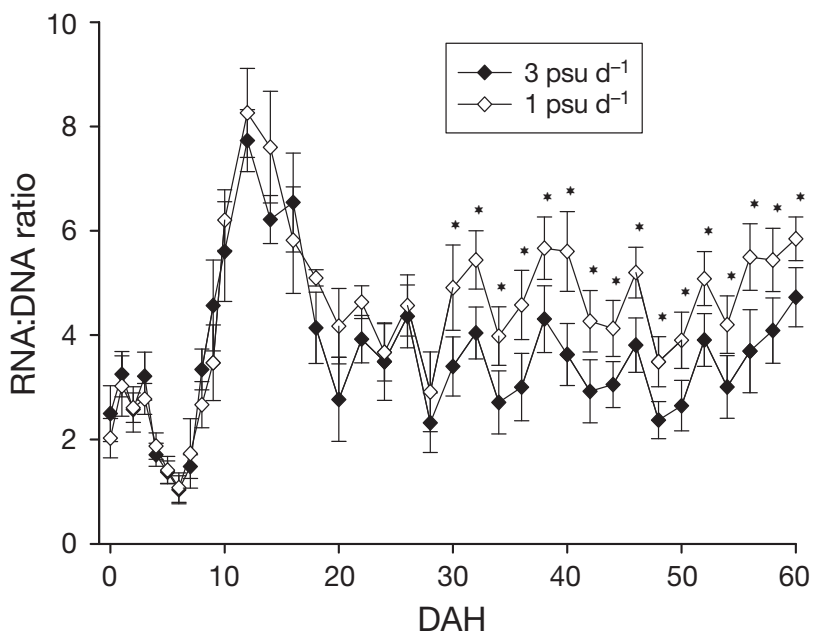

Fig. 4. Takifugu obscurus. Change of RNA/DNA ratios during the rearing experiment, DAH: days after hatching; means $\pm \mathrm{SD}, \mathrm{n}=5,{ }^{*} \mathrm{p}<0.05$ 


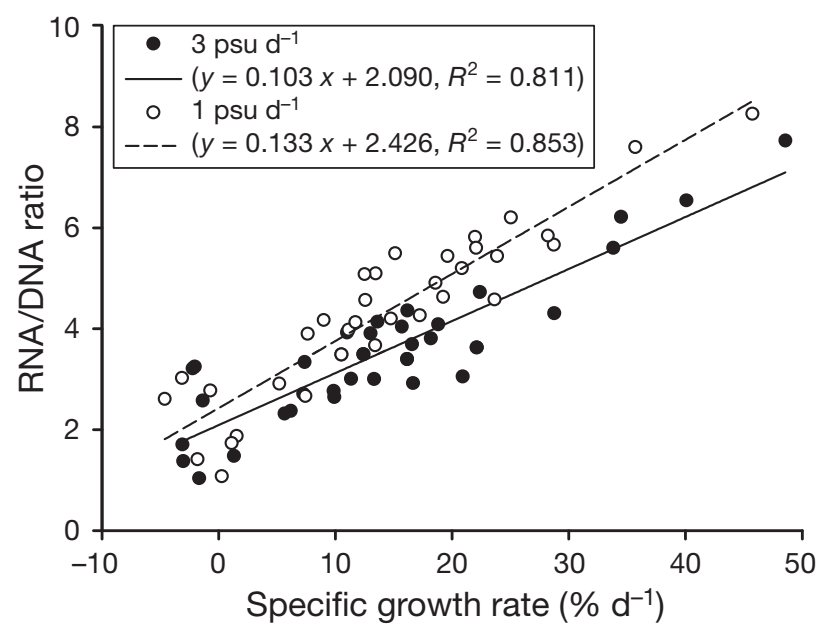

Fig. 5. Takifugu obscurus. Relationship between the RNA/DNA ratio and specific growth rate during the rearing experiment. Lines fitted by linear regression analysis

the $1 \mathrm{psu} \mathrm{d}^{-1}$ group and on Day 5 after initiation in the $3 \mathrm{psu} \mathrm{d}^{-1}$ group (Fig. 6b).

In the third starvation experiment, significant differences in weight between the fed and starved groups appeared on Day 5 after initiation in the $1 \mathrm{psu} \mathrm{d}^{-1}$ group and on the following day in the $3 \mathrm{psu} \mathrm{d}^{-1}$ group $(p<0.05)$ (Fig. 6c). Significant differences $(p<0.05)$ in the rate of weight gain and loss were observed between the salinity treatments.

The RNA/DNA ratios of the larvae right after hatching dramatically decreased in both groups from 3 to 6 DAH. After an initial reduction in the RNA/DNA ratio, an increase was observed in the fed group starting at $7 \mathrm{DAH}$ (Fig. 7a). On the other hand, the RNA/ DNA ratio of the starved group was not changed until Day 15, when all larvae died. The significant difference in the RNA/DNA ratio between the fed and starved groups appeared on Day 4 in the $1 \mathrm{psu} \mathrm{d}^{-1}$ group and Day 5 in the 3 psu d $\mathrm{d}^{-1}$ group ( $\left.\mathrm{p}<0.05\right)$.

RNA/DNA ratios of the fed group dramatically decreased from Day 3 after initiation to Day 7 after initiation, and a significant difference was recorded in the RNA/DNA ratio between the two groups with different salinity change rates (Fig. 7b). The RNA/DNA ratio of the $1 \mathrm{psu} \mathrm{d}^{-1}$ group was higher than that of the $3 \mathrm{psu} \mathrm{d}^{-1}$ group. Significant differences in the RNA/DNA ratio between the fed and starved groups were observed from Day 3 after initiation in the $1 \mathrm{psu} \mathrm{d}^{-1}$ group and from Day 4 after initiation in the $3 \mathrm{psu} \mathrm{d}^{-1}$ group $(\mathrm{p}<0.05)$ (Fig. 7b)

The results of the third starvation experiment, starting at $44 \mathrm{DAH}$, were similar to the second experiment and showed significant differences in the RNA/DNA
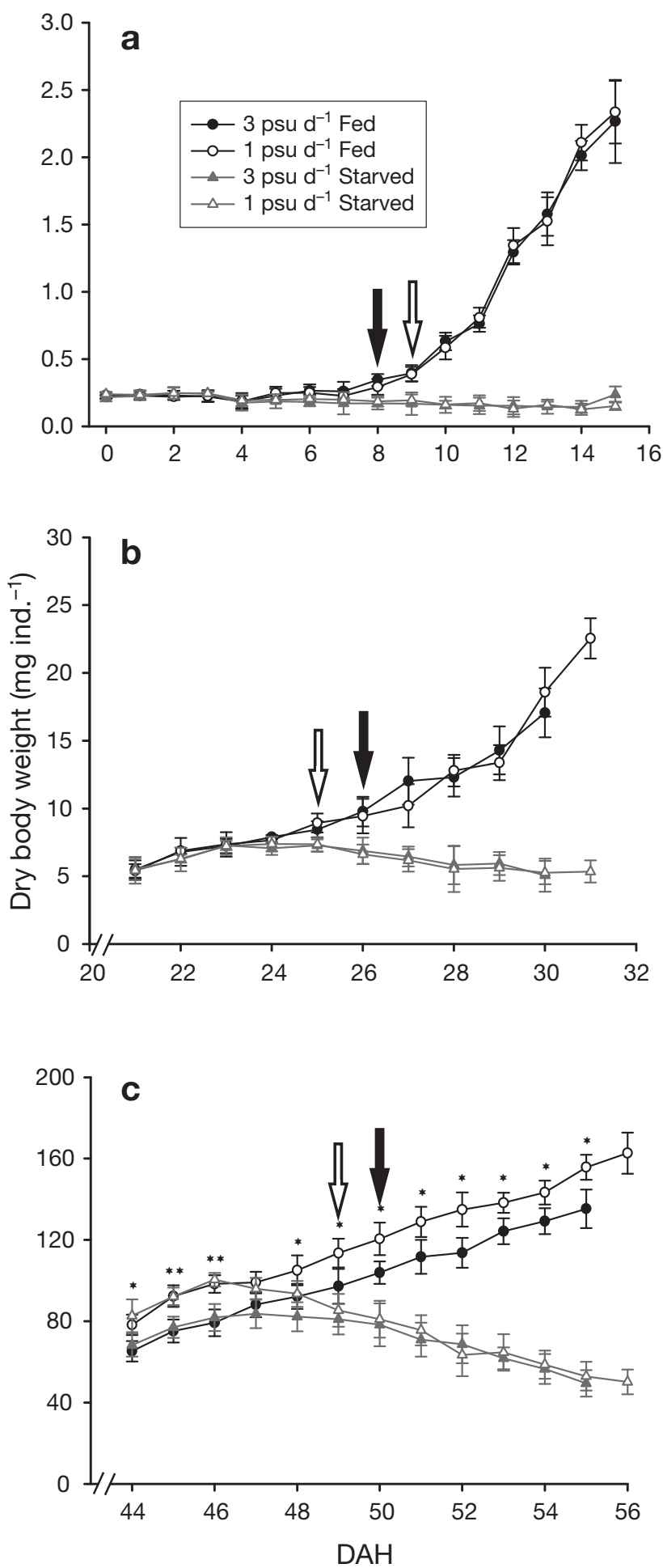

Fig. 6. Takifugu obscurus. Change of dry body weight during the starvation experiment according to the developmental stage, DAH: days after hatching. (a) Larvae: 0 to $15 \mathrm{DAH}$,

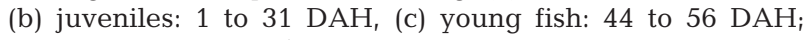
means $\pm \mathrm{SD}, \mathrm{n}=10,{ }^{*} \mathrm{p}<0.05$. Arrows indicate beginning of significant difference between fed and starved groups (1 psu d ${ }^{-1}$ group [open arrow], $3 \mathrm{psu} \mathrm{d}^{-1}$ group [closed arrow]) 

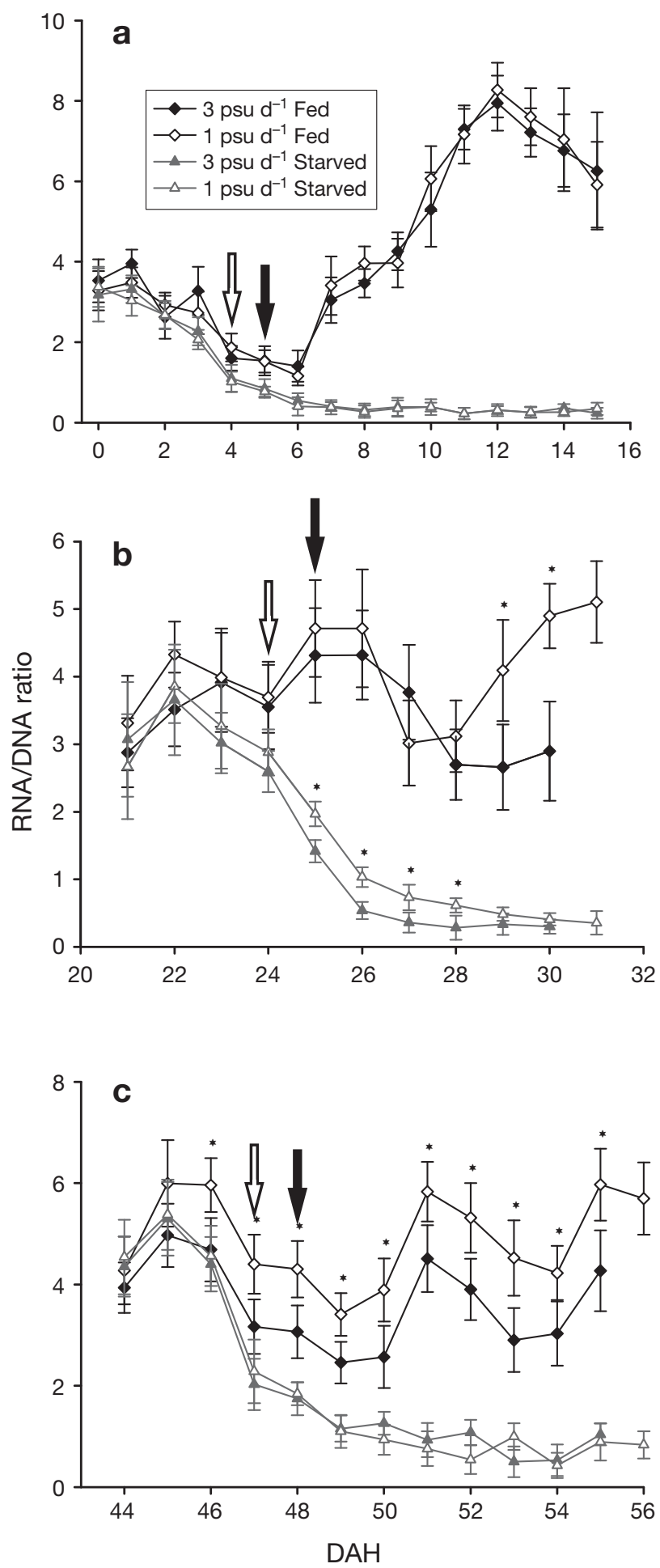

Fig. 7. Takifugu obscurus. Change of RNA/DNA ratios of the fed and starved groups during the starvation experiment according to the developmental stage, DAH: days after hatching. (a) Larvae: 0 to $15 \mathrm{DAH}$, (b) juveniles: 21 to $31 \mathrm{DAH}$, (c) young fish: 44 to $56 \mathrm{DAH}_{;}$means $\pm \mathrm{SD}, \mathrm{n}=10,{ }^{*} \mathrm{p}<0.05$. Arrows indicate beginning of significant difference between fed and starved groups (1 $\mathrm{psu} \mathrm{d}^{-1}$ group [open arrow], $3 \mathrm{psu} \mathrm{d}^{-1}$ group [closed arrow]) ratio between the fed and starved groups, which appeared on Day 3 after start of the experiment in the $1 \mathrm{psu} \mathrm{d}^{-1}$ group and on Day 4 after initiation in the $3 \mathrm{psu}$ $\mathrm{d}^{-1}$ group $(\mathrm{p}<0.05)$ (Fig. 7c). Although there was no difference in the RNA/DNA ratios between the 2 salinity change rates in the starved group, the RNA/DNA ratio of the $1 \mathrm{psu} \mathrm{d}^{-1}$ group was significantly higher $(\mathrm{p}<0.05)$ than that of the 3 psu d $^{-1}$ group from Day 2 after initiation and until the end of the experiment (Fig. 7c).

\section{DISCUSSION}

\section{Determination of nutritional status of reared fish}

The reduction in initial dry weight of newly hatched larvae was likely caused by yolk sac absorption prior to the first feeding. On the other hand, the RNA content increased to some degree before yolk sac absorption was completed. Though this was not significant, it may be due to the active formation of the organs and skeletal system during this period. In other words, energy for development was needed during this period, and this energy was not provided by exogenous food, but originated from the yolk sac.

Westerman \& Holt (1994) suggested that growth at the cellular level in rapidly developing larvae is characterized by rapid cell division or hyperplasia from hatching to completion of the yolk sac stage, followed by continued rapid cell divisions combined with increasing cell size or hypertrophy after feeding commences. Hjort (1914) hypothesized that the period of transition from endogenous energy sources to exogenous feeding is critical and that distribution and abundance of appropriately-sized prey organisms during this period control the subsequent success of the year-class. In the present study, the RNA/DNA ratio decreased after yolk sac absorption. Clemmesen \& Doan (1996) and McNamara et al. (1999) reported the same result in cod Gadus morhua larvae. Jaworski \& Kamler (2002) reported that an energy deficit may exist before the larvae become capable of exogenous feeding, and suggested that the amount of yolk sac consumption was too low to meet the energy expenditures of the larvae. Feeding larvae also showed signs of incipient starvation, suggesting that the larvae have to learn to capture prey organisms efficiently, while failure to capture sufficient prey seems to cause the observed decrease in the RNA/DNA ratio (Clemmesen 1987). Subsequently, a dramatic increase of the RNA/DNA ratio is likely due to a dramatic increase of the RNA compared to the DNA content, which only gradually increased. This indicates successful conversion toward the exogenous nutritional stage and means that continuous growth can be maintained, 
which suggests the importance of suitable food to be offered during these periods. On the other hand, the RNA/DNA ratio dropped dramatically after an initial peak, caused by stagnation of the RNA content as compared to a continuously increasing DNA content. This period has specific characteristics associated with the developmental stage, such as the beginning of notochord flexion and full completion of the fin ray, so hyperplasia is more emphasized than hypertrophy with respect to cellular activity. This pattern of change in the RNA/DNA ratio is the same as the results observed by Clemmesen (1987) for herring Clupea harengus and turbot Scophthalmus maximus and by Richard et al. (1991) for Solea solea. However, the stagnation of RNA content maintained over almost $15 \mathrm{~d}$ (14 to $28 \mathrm{DAH}$ ), together with the cessation of feeding with rotifers at $13 \mathrm{DAH}$, seem to have caused the observed decrease in the RNA/DNA ratio. These results could be interpreted as an unbalanced food conversion. Another low RNA/DNA ratio was detected at $28 \mathrm{DAH}$, and supply of animal feed was finished by $30 \mathrm{DAH}$. After $30 \mathrm{DAH}$ only the artificial formula diet was supplied, but the RNA/DNA ratio increased over the next day, likely because enough time had elapsed (ca. $2 \mathrm{wk}$ ) to allow adaptation to the new food. These results suggest that, for aquaculture of this species, an ample time overlap during transition of food items is an important factor. Furthermore, studies of RNA/DNA ratios in relation to growth and food availability seem to be worthwhile subjects to pursue.

A significant difference of growth between the $1 \mathrm{psu}$ $\mathrm{d}^{-1}$ and the $3 \mathrm{psu} \mathrm{d}^{-1}$ group was evident from 36 DAH. Consequently, the group exposed to the relatively slow increase in salinity showed better growth. Imsland et al. (2002) reported a similar result in that juvenile turbot maintained at lower salinities tended to have higher overall RNA/DNA ratios than fish kept at higher salinities. According to a study regarding the morphological development of Takifugu obscurus, the conversion from larval to juvenile stages occurs at ca. 26 DAH (Jang 1996). During conversion, active protein synthesis occurs as well as an increase in continuous cell number, which brings about accelerated growth. In the present study, a significant difference in the RNA/DNA ratio among the 2 different salinity groups appeared at $30 \mathrm{DAH}$, which matches the time of conversion from larval to juvenile stages. Consequently, the difference of growth in proportion between the two salinity change rates can be explained by the difference in energy consumed in order to maintain homeostasis. In the lower salinity change rate group, this energy was then available to perform other work, such as maintaining body functions, swimming and synthesizing new tissue in the form of growth or reproductive products. Avella et al. (1990) reported that a smolting species, the coho salmon Oncorhynchus kisutch was affected by changes in external salinities. Morgan \& Iwama (1991) also reported that salinity affected growth and metabolism of the juvenile rainbow steelhead trout Oncorhynchus mykiss and the fall Chinook salmon Oncorhynchus tshawytscha. In the present study, the RNA/DNA ratios and the SGR in the group in which salinity was increased by $1 \mathrm{psu} \mathrm{d}^{-1}$ showed a high correlation compared to the group in which salinity was increased by $3 \mathrm{psu} \mathrm{d}^{-1}$. Ehrlich (1974) and Love (1970) proposed that the change of a biochemical index, such as the RNA/DNA ratio, had a closer relationship to larval size than age in the early life history of fishes. This is an important consideration that should be taken into account when planning a growth study for other commercially used species. In other words, when the RNA/DNA ratio is used as an index of growth regarding the change of an environmental condition, developmental stage and fish size must be taken into consideration.

A difference in growth occurred under different salinity change rates, and the difference in growth was confirmed through correlation of the RNA/DNA ratios of the 2 groups. Therefore, we demonstrated that RNA/DNA ratios can be used as growth indices with respect to culture salinity levels for aquaculture species such as Takifugu obscurus.

\section{Effect of starvation on RNA/DNA ratios}

Starvation is generally accepted to be an important factor affecting the recruitment of fish larvae (Blaxter \& Staines 1971, Theilacker 1986). The present study was performed in order to understand the effect of starvation on growth during two developmental stages of Takifugu obscurus, larvae and juveniles, at different salinity change rates. Change in growth was tracked via quantitative changes in the RNA/DNA ratio. In our experiment, decreases in RNA content and increases in DNA content were observed under all starving conditions (J. H. Kim et al. unpubl. data). Clemmesen (1987) and Raae et al. (1988) observed similar results on the herring Clupea harengus, turbot Scophthalmus maximus and cod Gadus morhua larvae, but did not show a clear relationship with the duration of the starvation interval, and therefore RNA/DNA ratios could not be used to calibrate the nutritional status (Clemmesen 1987). Raae et al. (1988) suggested that higher DNA contents of starved larvae might be the result of residual cellular energy being used for rapid, unscheduled DNA synthesis as cellular control mechanisms degenerate due to the lack of sufficient nutrition.

DNA content increased slightly in the starved group until $4 \mathrm{DAH}$, but did not change after the yolk was 
completely absorbed. Buckley (1981) suggested that DNA content and cell number did not decrease, but were preserved in the larvae of the winter flounder Pseudopleuronectes americanus during starvation. The decrease in RNA content and slight increase or maintenance of DNA content after yolk absorption were also observed in studies of herring and turbot (Clemmesen 1987), Solea solea (Richard et al. 1991), and a study of Atlantic cod Gadus morhua (Raae et al. 1988). Bulow (1987) suggested that the body weight of the golden shiner Notemigonus crysoleucas decreased when the RNA/DNA ratio was smaller than 2.0, while it increased quickly when it was more than 4.0. In a study of food density and starvation for the striped bass Morone saxatalis, Wright \& Martin (1985) suggested that larvae face up to starvation if the RNA/DNA ratio is less than 2.0. The RNA/DNA ratios were between 0.8 and 1.5 in the starved group of the present study. The difficulty of directly comparing results between studies using different methods for the determination of RNA/DNA ratios has been pointed out by Caldarone \& Buckley (1991). Caldarone et al. (2006) verified that interprotocol variance in RNA and DNA contents was considerable among different methodologies and recommended an average DNA/RNA slope ratio to standardize results obtained from different spectrofluorometric protocols to allow for meaningful comparisons of the data. The average DNA/RNA slope ratio was 1.78 in the present study, which allowed it to be used directly in comparisons with the RNA/DNA results of other studies.

A significant difference in body weight and RNA/DNA ratio between the fed and starved groups appeared early in the group in which salinity was changed gradually ( $1 \mathrm{psu} \mathrm{d}^{-1}$ ), except for body weight in the first experiment $(p<0.05)$ (Fig. 6). In addition, a significant difference in RNA/DNA ratios between the fed and starved groups was observed a day earlier than a difference in dry weight $(p<0.05)$ (Fig. 7). The above results suggest that a decrease in RNA/DNA ratios can be viewed as an early warning to alert fish farm managers to the danger of starvation of reared river pufferfish larvae and juveniles, more so than observing morphological changes such as dry body weight.

We verified the usability of RNA/DNA ratios as an index of starvation and demonstrated that the analysis of RNA/DNA ratios provides valid results with a faster and higher sensitivity than measures of weight to evaluate starved larvae and juveniles of Takifugu obscurus. Moreover, we confirmed that salinity change at a suitable rate is an important environmental factor for the maintenance of fast growth during $T$. obscurus early life stages. In other words, a sudden salinity change can be a potentially limitating factor of fish growth, even though the river pufferfish has ample adaption ability for salinity. The RNA/DNA ratio was used as a means to track the change of growth in response to type and quality of feed and water temperature at specific growth stages, but more reliable data is needed to understand growth and nutritional conditions. We demonstrated that the RNA/DNA ratio can be used as an index of growth and starvation state during the early life cycle of river pufferfish. Further studies and collection of field samples are needed in order to apply the laboratory results to wild stock.

Acknowledgements. This research was undertaken with support from the Inha University grant program.

\section{LITERATURE CITED}

Aparicio S, Chapman J, Stupka E, Putnam N and others (2002) Whole-genome shotgun assembly and analysis of the genome of Fugu rubripes. Science 297:1301-1310

Avella M, Young G, Prunet P, Schreck CB (1990) Plasma prolactin and cortisol concentrations during salinity challenges of coho salmon (Oncorhynchus kisutch) at smolt and post-smolt stages. Aquaculture 91:359-372

Berdalet D, Roldan C, Olivar MP, Lysnes K (2005) Quantifying RNA and DNA in planktonic organisms with SYBR Green II and nucleases. Part A. Optimization of the assay. Sci Mar 69:1-16

Blaxter JHS, Hempel G (1963) The influence of egg size on herring larvae (Clupea harengus L). J Cons Perm Int Explor Mer 28:211-240

Blaxter JHS, Staines M (1971) Food searching potential in marine fish larvae. In: Crisp DJ (ed) 4th Eur Mar Biol Symp, Cambridge University Press, Cambridge, p 467-485

Buckley LJ (1980) Changes in ribonucleic and deoxyribonucleic acid, and protein content during ontogenesis in winter flounder Pseudopleuronectes americanus, and effect of starvation. Fish Bull 77:703-708

Buckley LJ (1981) Biochemical changes during ontogenesis of cod (Gadus morhua L) and winter flounder (Pseudopleuronectes americanus) larvae. Rapp P-V Reùn Cons Int Explor Mer 178:547-552

Buckley LJ, Turner SI, Halavik TA, Smigielski AS, Drew SM, Laurence GC (1984) Effects of temperature and food availability on growth, survival and RNA-DNA ratio of larval sand lance (Ammodytes americanus). Mar Ecol Prog Ser 15: 91-97

Bulow FJ (1987) RNA-DNA ratios as indicators of growth $n$ fish: a review. In: Summerfeld RC, Hall GE (eds) Age and growth of fish. Iowa State University Press, Ames, p 45-64

Caldarone EM, Buckley LJ (1991) Quantitation of DNA and RNA in crude tissue extracts by flow injection analysis. Anal Biochem 199:137-141

Caldarone EM, Clemmesen CM, Berdalet E, Miller TJ and others (2006) Intercalibration of four spectrofluorometric protocols for measuring RNA/DNA ratios in larval and juvenile fish. Limnol Oceanogr Methods 4:153-163

Catalan IA, Olivar MP, Palomera I, Berdalet E (2006) Link between environmental anomalies, growth and condition of pilchard Sardina pilchardus larvae in the northwestern Mediterranean. Mar Ecol Prog Ser 307:219-231

Clemmesen CM (1987) Laboratory studies on RNA/DNA ratios of starved and fed herring (Clupea harengus) and 
turbot (Scophthalmus maximus) larvae. J Cons Int Explor Mer 43:122-128

Clemmesen CM (1988) A RNA and DNA fluorescent technique to evaluate the nutritional condition of individual marine fish larvae. Meeresforschung 32:134-143

Clemmesen CM, Doan T (1996) Does otolith structure reflect the nutritional condition of a fish larva? Comparison of otolith structure and biochemical index (RNA/DNA ratio) determined on cod larvae. Mar Ecol Prog Ser 138:33-39

Dortch Q, Roberts TL, Clayton JR Jr, Ahmed SI (1983) RNA/DNA ratios and DNA concentrations as indicators of growth rate and biomass in planktonic marine organisms. Mar Ecol Prog Ser 13:61-71

Ehrlich KF (1974) Chemical changes during growth and starvation of larval Pleuronectes platessa. Mar Biol 24:39-48

Gwak WS, Seikai T, Tanaka M (1999) Evaluation of starvation sta-tus of laboratory-reared Japanese Flounder Paralichthys olivaceus larvae and juveniles based on morphological and histological characteristics. Fish Sci 65: 339-346

Gwak WS, Tsusaki T, Tnanka M (2003) Nutritional condition, as evaluated by RNA/DNA ratios, of hatchery-reared Japanese flounder from hatch to release. Aquaculture 219: 503-514

Hjort J (1914) Fluctuations in the great fisheries of Northern Europe viewed in the light of biological research. Rapp P-V Reùn Cons Int Explor Mer 160:1-228

Imsland AK, Foss A, Bonga SW, Ham EV, Stefansson SO (2002) Comparison of growth and RNA:DNA ratios in three populations of juvenile turbot reared at two salinities. J Fish Biol 60:288-300

Jang SI (1996) Induced ovulation by using human chorionic gonadotropin and gonadotropin-releasing hormone analogue plus pimozide in yellow puffer, Takifugu obscures. J Aquacult 9:3-10 (in Korean)

Jaworski A, Kamler E (2002) Development of a bioenergetics model for fish embryos and larvae during the yolk feeding period. J Fish Biol 60:785-809

Kato A, Doi H, Nakada T, Sakai H, Hirose S (2005) Takifugu obscurus is a euryhaline fugu species very close to Takifugu rubripes and suitable for studying osmoregulation. BMC Physiol 5:18

Kim JH, Wang SY, Kim IC, Ki JS, Raisuddin S, Lee JS, Han KN (2008) Cloning of a river pufferfish (Takifugu obscures) metallothionein cDNA and study of its induction profile in cadmium-exposed fish. Chemosphere 71:1251-1259

Kono N, Tsukamoto Y, Zenitani H (2003) RNA:DNA ratio for diagnosis of the nutritional condition of Japanese anchovy Engraulis japonicus larvae during the first-feeding stage. Fish Sci 69:1096-1102

Kucera CJ, Faulk CK, Holt GJ (2002) The effect of spawning salinity on eggs of spotted seatrout (Cynoscion nebulosus, Cuvier) from two bays with historically different salinity regimes. J Exp Mar Biol Ecol 272:147-158

Love RM (1970) The chemical biology of fishes. Academic Press, London

Mansfield ES, Worley JM, McKenzie SE, Surrey S, Rappaport E, Fortina P (1995) Nucleic acid detection using nonradioactive labeling methods. Mol Cell Probes 9:145-156

Editorial responsibility: Jana Davis,

Annapolis, Maryland, USA
Martin FD, Wright DA (1987) Nutritional state analysis and its use in predicting striped bass recruitment: laboratory calibration. Am Fish Soc Symp 2:109-114

McNamara PT, Caldarone EM, Buckley LJ (1999) RNA/DNA ratio and expression of $18 \mathrm{~S}$ ribosomal RNA, actin and myosin heavy chain messenger RNAs in starved and fed larval Atlantic cod (Gadus morhua). Mar Biol 135: $123-132$

Morgan JD, Iwama GK (1991) Effects of salinity on growth, metabolism, and ion regulation in juvenile rainbow and steelhead trout (Oncorhynchus mykiss) and fall chinok salmon (Oncorhynchus tshawytscha). Can J Fish Aquat Sci 48:2083-2094

> Raae AJ, Opstad I, Kvenseth P, Walther BT (1988) RNA, DNA and protein during early development in feeding and starved cod (Gadus morhua L) larvae. Aquaculture 73: 247-259

> Richard P, Bergeron JP, Boulhic M, Galois R, Person-Le Ruyet J (1991) Effect of starvation on RNA, DNA and protein content of laboratory-reared larvae and juveniles of Solea solea. Mar Ecol Prog Ser 72:69-77

Sambrook J, Fritsch EF, Maniatis T (1989) Molecular cloning: A laboratory manual. Book 2, CSHL Press, Cold Spring Harbor, New York

Schmidt DM, Ernst JD (1995) A fluorometric assay for the quantification of RNA in solution with nanogram sensitivity. Anal Biochem 232:144-146

Tandler A, Anav FA, Choshniak I (1995) The effect of salinity on growth rate, survival and swimbladder inflation in gilthead seabream, Sparus aurata, larvae. Aquaculture 135: 343-353

Tardif D, Glémet $\mathrm{H}$, Brodeur P, Mingelbier M (2005) RNA/DNA ratio and total length of yellow perch (Perca flavescens) in managed and natural wetlands of a large fluvial lake. Can J Fish Aquat Sci 62:2211-2218

Theilacker GH (1986) Starvation induced mortality of young sea-caught jack mackerel, Trachurus symmetricus, determined with histological and morphological methods. Fish Bull (Wash DC) 84:1-17

Westerman M, Holt GJ (1994) RNA:DNA ratio during the critical period and early larval growth of the red drum Sciaenops ocellatus. Mar Biol 121:1-9

Wright D, Martin FD (1985) The effect of starvation on RNADNA ratios and growth of larval striped bass, Morone saxatalis. J Fish Biol 27:479-485

Yang Z, Chen YF (2003) Length-weight relationship of obscure puffer (Takifugu obscurus) during spawning migration in the Yangtze River, China. J Freshw Ecol 18: 349-352

> Yang Z, Chen YF (2004) Induced ovulation in obscure puffer Takifugu obscures by injections of LHRH-a. Aquacult Int 12: 215-223

- Yang Z, Chen YF (2006) Salinity tolerance of embryos of obscure puffer Takifugu obscurus. Aquaculture 253: 393-397

- Yin MC, Blaxter JHS (1986) Morphological changes during growth and starvation of larval cod (Gadus morhua L) and flounder (Platichthys flesus L). J Exp Mar Biol Ecol 104: 215-228

Submitted: February 5, 2008; Accepted: August 20, 2008

Proofs received from author(s): November 18, 2008 